\begin{tabular}{|c|c|c|}
\hline $\begin{array}{l}\text { OPEN ACCESS } \\
\text { Vol.4 No. 2: } 71-83 \\
\text { Tahun } 2021 \\
\text { Artikel penelitian 圆 }\end{array}$ & 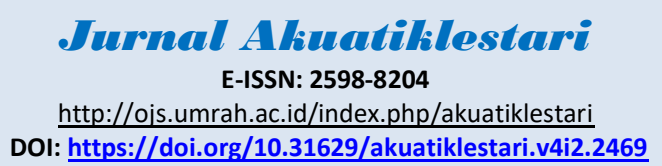 & $\begin{array}{l}Q= \\
\vdots \\
\vdots=- \\
0=\end{array}$ \\
\hline
\end{tabular}

\title{
Keanekaragaman Spons pada Ekosistem Padang Lamun di Perairan Malang Rapat, Kabupaten Bintan
}

\section{Diversity of Sponge on the Seagrass Ecosystem in the Waters of Malang Rapat, Bintan Regency}

\section{Fidayat $^{1 \bowtie}$, Febrianti Lestari ${ }^{1}$, Aditya Hikmat Nugraha ${ }^{2}$}

1 Manajemen Sumberdaya Perairan, Fakultas Ilmu Kelautan dan Perikanan, Universitas Maritim Raja Ali Haji, Tanjungpinang, Indonesia 29111

2 Ilmu Kelautan, Fakultas Ilmu Kelautan dan Perikanan, Universitas Maritim Raja Ali Haji, Tanjungpinang, Indonesia 29111

\section{■ Info Artikel:}

Diterima: 18 Agustus 2020

Revisi: 20 November 2020

Disetujui: 27 Mei 2021

Dipublikasi: 30 Mei 2021

\section{Keyword:}

Keanekaragaman, Spons, Ekosistem Padang Lamun, Kabupaten Bintan

\footnotetext{
$\triangle$ Penulis Korespondensi: Fidayat

Manajemen Sumberdaya Perairan Fakultas IImu Kelautan dan Perikanan Universitas Maritim Raja Ali Haji Tanjungpinang, Indonesia 29111

Email: hyayat265@gmail.com
}

\begin{abstract}
ABSTRAK. Secara ekologis ekosistem padang lamun memiliki peranan penting pada daerah pesisir, antara lain sebagai produsen primer pada perairan dangkal, daerah pembesaran, pemijahan dan juga merupakan sumber makanan penting bagi beberapa jenis organisme. Salah satu biota asosiatif di ekosistem lamun adalah spons. Spons adalah hewan berpori yang hidup dengan cara menyaring makanannya dari air laut dan bersifat bentik. Tujuan dari penelitian ini adalah untuk mengetahui tingkat kerapatan lamun, mengetahui jenis kepadatan spons, mengetahui karakter penciri lingkungan kepadatan spons, kerapatan lamun dan parameter lingkungan perairan. Penelitian ini dilakukan dengan metode purposive sampling. Hasil penelitian ditemukan 6 jenis spons Cinachyra sp., Raspailia arbuscula, Dendrilla antarctica, Petrosia sp., Tetrapocillon Novaezealandiae, Cinachyrella sp. Nilai kerapatan lamun berkisar antara $181-312 \mathrm{ind} / \mathrm{m}^{2}$ dengan kategori pada setiap stasiun di kategorikan sangat rapat. Kepadatan spons sebesar $5,2 \mathrm{ind} / \mathrm{m}^{2}-6 \mathrm{ind} / \mathrm{m}^{2}$. Indeks keanekaragaman spons berkisar antara $0-0,4$, pada semua stasiun dikategorikan rendah. Hasil analis komponen utama atau PCA menunjukan stasiun satu parameter lingkungan perairan tidak memiliki kedekatan dengan kerapatan lamun dan kepadatan spons. Sedangkan pada stasiun dua kepadatan spons memiliki kedekatan dengan parameter lingkungan perairan seperti $\mathrm{pH}$ dan suhu, pada stasiun tiga kerapatan lamun memiliki kedekatan dengan parameter lingkungan perairan seperti salinitas dan kecerahan.
\end{abstract}

\begin{abstract}
Ecologically seagrass ecosystems have an important role in coastal areas, such as primary producers in shallow waters, enlargement areas, spawning and also an important food source for several types of organisms (in the form of detritus). One of the associative biota in seagrass ecosystems is sponges. Sponges are porous animals that live by filtering food from sea water and are benthic. The purpose of this study was to determine the seagrass density level, determine the type of sponge density, determine the environmental characteristics of sponge density, seagrass density and water environmental parameters. This research was conducted with a purposive sampling method. The results found 6 types of sponge Cinachyra sp, Raspailia arbuscula, Dendrilla antarctica, Petrosia sp, Tetrapocillon novaezealandiae, cinachyrella sp. Seagrass density values range from $181-312 \mathrm{ind} / \mathrm{m}^{2}$ with categories at each station categorized as very tight. Sponge density is $5.2 \mathrm{ind} / \mathrm{m}^{2}-6 \mathrm{ind} / \mathrm{m}^{2}$. The spongy diversity index ranges from $0-0.4$, at all stations categorized as low. The results of the main component analyst or PCA show that the environmental parameters of the waters do not have root characteristics with the density and density of the sponge. The density of the sponge has roots characterized by environmental parameters of the water such as $\mathrm{pH}$ and temperature. Seagrass density has a root characteristic with parameters of aquatic environments such as salinity and brightness.
\end{abstract}

How to cite this article

Fidayat, Lestari, F., \& Nugraha, A.H. (2021). Keanekaragaman Spons pada Ekosistem Padang Lamun di Perairan Malang Rapat, Kabupaten Bintan. Jurnal Akuatiklestari, 4(2): 71-84. DOI: https://doi.org/10.31629/akuatiklestari.v4i2.2469

\section{PENDAHULUAN}

Ekosistem padang lamun di Kabupaten Bintan banyak ditemui terutama wilayah perairan Bintan Timur di antaranya, Desa Malang Rapat, dan Desa Berakit dengan luas \pm 2.918,36 Ha dengan kondisi baik sekitar 58,01\% (DKP Kabupaten Bintan, 2011). Secara ekologis ekosistem padang lamun memiliki peranan penting pada daerah pesisir, antara lain sebagai produsen primer pada perairan dangkal, daerah pembesaran, pemijahan dan juga merupakan 
sumber makanan penting bagi beberapa jenis organisme (dalam bentuk detritus), selain itu lamun juga dapat berfungsi untuk menstabilkan sedimen dasar melalui model perakaran yang menjalar dan padat, keanekaragaman hayati lamun tertinggi ditemukan di wilayah Indo-Pasifik, khususnya perairan Indonesia. Sebagai negara dengan tinggi keanekaragaman hayati, terdapat 12 spesies dari 69 spesies yang ditemukan di dunia. Lamun di Indonesia ditemukan didaerah pesisir dan pulau-pulau kecil di mana ia dapat hidup sampai kedalaman 40 meter (Kawaroe et al., 2016).

Salah satu biota asosiatif di ekosistem lamun adalah spons. Spons adalah hewan berpori yang hidup dengan cara menyaring makanannya dari air laut dan bersifat bentik. Hewan ini dapat hidup dengan baik pada arus air yang kuat, karena aliran air tersebut menyediakan kumpulan makanan dan oksigen. Makanan spons terdiri dari detritus organik seperti bakteri, zooplankton dan phytoplankton yang secara elektif ditangkap oleh sel-sel berbulu cambuk, salah satu kelas dari spons adalah Demospongiae yang mencakup 90\% dan ada sekitar 4500 - 5000 jenis, dari total jenis yang hidup di dunia (Sabdono, 2011). Penelitian mengenai keanekaragaman spons pada ekositem padang lamun di Perairan Malang Rapat belum banyak diketahui. Pentingnya informasi mengenai spons adalah untuk dapat menjadi bahan penelitian lebih lanjut mengenai bahan bioaktif dan bakteri didalam jaringan spons berdasarkan keanekaragaman spons yang memiliki manfaat penting. Melihat potensi keberadaan sumberdaya spons pada lamun yang dimiliki banyak manfaat, tentunya Perairan Malang Rapat juga menyimpan potensi jenis spons sehingga perlu dilakukanya penelitian terkait keanekaragaman spons pada ekosistem lamun.

\section{BAHAN DAN METODE}

\subsection{Waktu dan Tempat}

Penelitian ini dilaksanakan pada bulan Februari-Mei 2020 berlokasi di Perairan Malang Rapat Kecamatan Gunung Kijang Kabupaten Bintan Provinsi Kepulauan Riau. Dapat di lihat pada Gambar 1.

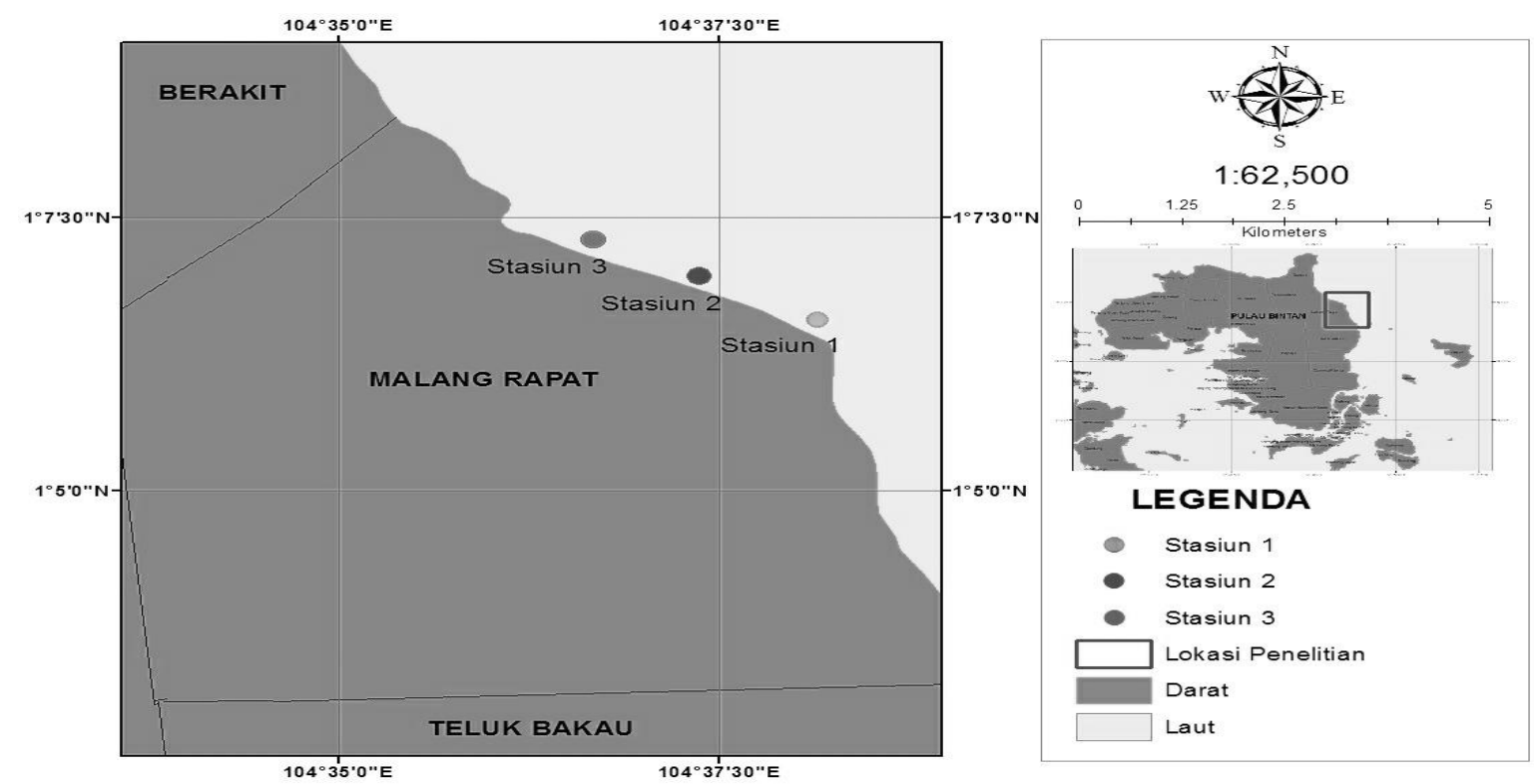

Gambar 1. Peta Lokasi Penelitian

\subsection{Alat dan Bahan}

Alat-alat yang digunakan dalam penelitian ini meliputi multitester untuk mengukur $\mathrm{DO}, \mathrm{pH}$, dan suhu, hand refraktometer untuk mengukur salinitas, secchi disk untuk mengukur kecerahan, roll meter untuk menentukan jarak antar titik dan transek kuadrat, GPS (Global Positioning System) menentukan koordinat stasiun pengamatan, transek kauadrat (50x50) mengamati jenis lamun dan spons yang ditemukan, alat tulis dan kertas untuk mencatat hasil pengamatan, kamera digitas dokumentasi, buku identifikasi untuk identifikasi lamun dan spons, plastik sampel tempat sampel yang dijumpai, kertas label penamaan sampel, aquades untuk membilas peralatan, botol sampel tempat sampel, oven mengeringkan substrat. Bahan yang digunakan dalam penelitian ini berupa objek penelitian yaitu spons.

\subsection{Prosedur Penelitian}

\subsubsection{Teknik Pengumpulan Data}

Metode yang digunakan dalam penelitian ini adalah metode survei, yaitu dengan pengamatan langsung dimana pengambilan data menggunakan teknik purposive sampling. Data primer didapatkan dari observasi langsung di lapangan berupa jenis dan kerapatan serta parameter lingkungan perairan yaitu: suhu, salinitas, $\mathrm{pH}$, kecerahan, kecepatan arus dan substrat. Hasil dari analisis data primer akan ditabulasikan dalam tabel dan dideskripsikan dengan data yang ada dengan literatur, sedangkan data sekunder didapatkan dari instansi pemerintah yang terkait dengan penelitian seperti Kantor Desa Malang Rapat. 


\subsubsection{Penentuan Stasiun dan Titik Sampling}

Penentuan stasiun penelitian mengacu kepada perbedaan karakteristik lingkungan sebagai berikut: Stasiun satu terletak di Perairan Kampung Kampe, terletak di daerah dengan pengaruh aktivitas wisata seperti bekarang dan perikanan memancing dengan substrat pasir putih yang juga dijumpai mangrove, lamun serta karang mati maupun karang hidup,bekas reklamasi pembangunan resort. Stasiun dua terletak di Tanjung Keling, terletak di daerah dengan pengaruh aktivitas yang tinggi dalam bidang perikanan terutama bagan apung dan aktivitas wisata seperti bekarang, memancing, hamparan ekosistem lamun. Stasiun tiga terletak di Pulau Pucung, terletak di daerah dengan pengaruh aktivitas yang tinggi dalam bidang perikanan terutama kja dan wisata seperti bekarang yang juga dijumpai hamparan ekosistem lamun dengan substrat pasir putih.

\subsubsection{Pengamatan Lamun dan Spons}

Metode yang di gunakan adalah metode transek garis di bentang tegak lurus kearah laut dari saat pertama kali ditemukan lamun dan spons, pada saat pengematan lamun dan spons line transek di pasang tegak lurus kearah laut sepanjang 100 meter, Dengan jarak antar transek 10 meter, dan jarak antar line 50 meter. Sehingga pengamatan dalam satu line transek ada ll plot transek.

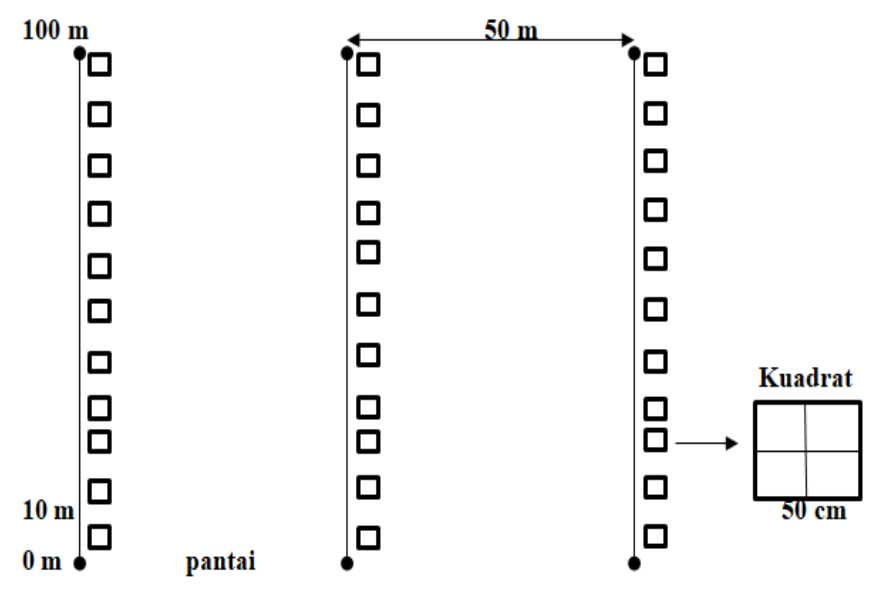

Gambar 2. Metode line transek kuadran (Rahmawati et al., 2014)

\subsubsection{Pengukuran Kualitas Perairan}

Pengukuran parameter kualitas perairan fisika, kimia seperti suhu, kecerahan, kecepartan arus, substrat, DO, pH, dan salinitas. Dapat dilihat pada Tabel 1.

Tabel 1. Parameter Kualitas Perairan

\begin{tabular}{cccc} 
No & Parameter & Alat/Metode & Keterangan \\
1 & Fisika & Multitester & Lapangan \\
& Suhu & Secchi disk & Lapangan \\
2 & Kecerahan & & \\
& Kimia & Multitester & Lapangan \\
& $\mathrm{pH}$ & Handrefractometer & Lapangan \\
& Salinitas & Multitester & Lapangan \\
\hline
\end{tabular}

\subsection{Analisis data}

\subsubsection{Kerapatan Lamun}

Kerapatan masing-masing jenis pada setiap stasiun dihitung dengan menggunakan rumus (Fachrul, 2007) sebagai berikut. Kategori kerapatan lamun berdasarkan (Gosari \& Haris, 2012) dapat dilihat pada Tabel 2.

Keterangan:

$$
D i=\frac{n i}{A}
$$

Di $\quad=$ Kerapatan jenis (tegakan $\left./ \mathrm{m}^{2}\right)$

ni $\quad=$ Jumlah individu (tegakan) ke -i dalam transek kuadrat

A $=$ Luas area sampling $\left(\mathrm{m}^{2}\right)$ 
Tabel 2. Kategori Nilai Kerapatan Lamun (Gosari \& Haris, 2012)

\begin{tabular}{ccc} 
Skala & Kerapatan $\left(\mathbf{i n d} / \mathbf{m}^{\mathbf{2}}\right.$ ) & Kondisi \\
5 & $>175$ & Sangat Rapat \\
4 & $125-175$ & Rapat \\
3 & $75-125$ & Agak Rapat \\
2 & $25-75$ & Jarang \\
1 & $<25$ & Sangat Jarang \\
\hline
\end{tabular}

\subsubsection{Kepadatan Spons}

Kepadatan spons adalah jumlah individu persatuan luas. Kelimpahan spons yang ada pada stasiun pengamatan spons dihitung berdasarkan (Fachrul, 2007):

Keterangan:

$$
K=\frac{n i}{A}
$$

$\mathrm{K}=$ Kepadatan jenis spons $\left(\mathrm{ind} / \mathrm{m}^{2}\right)$

$\mathrm{n}_{\mathrm{i}} \quad=$ Jumlah individu spesies spons (ind)

A $\quad=$ Luas transek $\left(\mathrm{m}^{2}\right)$

\subsubsection{Indeks keanekargaaman spons}

Tingkat keanekaragaman spons yang ada dalam stasiun pengamatan dapat ditentukan dengan menggunakan rumus indeks keanekaragaman Shannon-Wiener (Bakus, 2007) yaitu:

Keterangan:

$$
H^{\prime}=-\sum P i \log P i
$$

$\mathrm{H}^{\prime}=$ Indeks keanekaragaman Shannon-Wiener

$S=$ Jumlah genus biota

$\mathrm{Pi}=$ Proporsi jumlah individu pada genus biota $(\mathrm{ni} / \mathrm{N})$

$\mathrm{ni}=$ Jumlah individu jenis ke- $\mathrm{i}$

$\mathrm{N}=$ Jumlah seluruh jenis

Tabel 3. Tingkat Keanekaragaman Jenis Shannon-Wiener

\begin{tabular}{cc} 
Nilai Keanekaragaman Jenis $\left(\mathbf{H}^{\prime}\right)$ & Tingkat Keanekaragaman Jenis \\
$\mathrm{H}^{\prime}<1.6$ & Rendah \\
$1.6<\mathrm{H}^{\prime} \leq 2.3$ & Sedang \\
$\mathrm{H}^{\prime}>2.3$ & Tinggi \\
\hline
\end{tabular}

\subsubsection{Analisis Kedekatan antara Kerapatan Lamun, Kepadatan Spons dan Parameter Lingkungan Perairan}

Karakter penciri spons dan lamun dianalisis menggunakan analisis komponen utama Principal Component Analysis (PCA) dengan software minitab 17.1 merupakan bagian dari analisis multivariat yang mempelajari akar ciri antara dua variabel atau lebih variabel dengan memperagakan baris dan kolom secara bersama dari tabel kontingensi. Analisis koresponden merupakan salah satu metode statistik deskriptif yang dirancang untuk menganalisa tabel kontingensi dua arah atau multi arah yang mengandung akar ciri antara variabel- variabel baris dan kolom. Analisis koresponden dibuat dengan langkah pertama menyusun tabel kontingensi berupa tabulasi silang dua variable atau lebih (Maulana, 2018).

\section{HASIL DAN PEMBAHASAN}

\subsection{Kondisi Umum Lokasi Penelitian}

Perairan Malang Rapat merupakan perairan landai dengan substrat pasir putih. Perairan Malang Rapat terletak di Kabupaten Bintan, secara geografis Kabupaten Bintan terletak antara 104 .612'.339 Lintang Selatan atau Lintang Utara dan 0. 981'.951 Bujur Timur atau Bujur Barat. Jumlah penduduk yang ada di Desa Malang Rapat sekitar 2.079 jiwa. Terletak di RT 01/RW 02. Desa Malang Rapat terdiri dari beberapa kampung diantaranya, Sebelah Utara: Desa Berakit, Sebelah Selatan: Kecamatan Teluk Bakau, Sebelah Timur : Laut Cina Selatan, dan Sebelah Barat : Toapaya Utara.

Hampir keseluruhan masyarakat menggunakan kelong dalam mengambil hasil laut. Selain itu terdapat pula pengunjung luar baik itu wisatawan lokal maupun mancanegara yang berniat untuk berwisata mengingat di sepanjang 
garis pantai Desa Malang Rapat disediakan pondok-pondok kecil yang dapat digunakan wisatawan untuk beristirahat. Ada juga sebagian pengunjung dan masyarakat lokal yang sengaja datang ke Desa Malang Rapat untuk berkarang mencari hasil laut sebagai konsumsi atau di perjualkan.

\subsection{Parameter Fisika dan Kimia Perairan}

Parameter lingkungan perairan yang dapat memengaruhi kehidupan spons dan lamun di perairan diantaranya adalah suhu, kecepatan arus, kecerahan, serta jenis substrat atau sedimen. Sedangkan parameter kimia yang juga dapat memengaruhi kehidupan spons dan lamun di perairan diantaranya adalah derajat keasaman $(\mathrm{pH})$, salinitas, oksigen terlarut (DO), Adapun hasil pengukuran parameter lingkungan perairan baik fisika maupun kimia dapat dilihat pada Tabel 4.

Tabel 4. Parameter Lingkungan Perairan

\begin{tabular}{|c|c|c|c|c|c|}
\hline Parameter & Satuan & 1 & Stasiun & 3 & Baku mutu \\
\hline $\begin{array}{c}\text { Fisika } \\
\text { Suhu } \\
\text { Kecerahan }\end{array}$ & $\begin{array}{l}{ }^{\circ} \mathrm{C} \\
\mathrm{M}\end{array}$ & $\begin{array}{c}29,23 \pm 0,32 \\
100 \pm 0\end{array}$ & $\begin{array}{c}29,50 \pm 0,45 \\
100 \pm 0\end{array}$ & $\begin{array}{c}29,57 \pm 0,51 \\
100 \pm 0\end{array}$ & $28-30$ \\
\hline $\begin{array}{c}\text { Kimia } \\
\text { Salinitas } \\
\text { Derajat } \\
\text { Keasaman }(\mathrm{pH})\end{array}$ & $\begin{array}{c}0 / 00 \\
-\end{array}$ & $\begin{array}{c}30,52 \pm 2,53 \\
7,63 \pm 0,14\end{array}$ & $\begin{array}{c}30,60 \pm 2,35 \\
7,78 \pm 0,06\end{array}$ & $\begin{array}{c}31,87 \pm 0,49 \\
7,67 \pm 0,06\end{array}$ & $\begin{array}{c}33-34 \\
7-8,5\end{array}$ \\
\hline Oksigen Terlarut & $\mathrm{mg} / \mathrm{L}$ & $7,63 \pm 0,61$ & $6,8 \pm 0,46$ & $6,7 \pm 0,59$ & $>5$ \\
\hline
\end{tabular}

Sumber : Data primer

*Keputusan Menteri Lingkungan Hidup No 51 Tahun 2004

Hasil pengukuran kualitas perairan pada lokasi penelitian di Perairan Malang Rapat menunjukan besarnya suhu pada stasiun satu sebesar 29,23, stasiun dua 29,50 dan stasiun tiga sebesar 29,57. Suhu tertinggi dijumpai pada stasiun tiga sedangkan suhu terendah pada stasiun satu. Data yang didapat dibandingkan dengan baku mutu air laut KEPMEN LH NO. 5l TAHUN 2004 dimana untuk parameter suhu berkisar antara $28-30^{\circ} \mathrm{C}$. Berdasarkan hasil tersebut, suhu pada lokasi penelitian masih berada pada kisaran yang baik untuk pertumbuhan lamun. kisaran suhu yang optimal bagi pertumbuhan spons yaitu $>18^{\circ} \mathrm{C}$, suhu rata-rata tahunan berkisar antara $23-25^{\circ} \mathrm{C}$, dengan suhu maksimal yang dapat ditoleran berkisar antara $36-40^{\circ} \mathrm{C}$, (Panggabean \& Setyadji, 2010).

Kecerahan perairan sangat dipengaruhi oleh sinar matahari yang masuk ke dalam perairan. Semakin tinggi intensitas cahaya matahari yang masuk ke dalam perairan maka semakin tinggi nilai kecerahan perairan tersebut. Pada lokasi penelitian diperoleh nilai kecerahan yang sangat tinggi yaitu $100 \%$. Hal tersebut berarti bahwa pada lokasi pengamatan penyinaran sinar matahari masih terjadi sampai kedalaman tertentu. Kecerahan yang tinggi disebabkan oleh sifat lamun yang mampu menangkap sedimen dan didukung oleh kecepatan arus saat penelitian yang relatif tenang. Lamun membutuhkan intensitas cahaya yang tinggi untuk melakukan proses fotosintesis, spons sangat menyukai perairan yang sangat jernih (Suharyanto, 2008).

Hasil pengukuran salinitas pada lokasi penelitian berkisar antara 30,52 - 31,87\%. Adanya perbedaan salinitas ditiap stasiun dipengaruhi adanya sirkulasi air laut dalam proses pasang surut air laut dan pengaruh curah hujan di Perairan Malang Rapat. Berdasarkan baku mutu air laut untuk biota laut pada Keputusan Menteri Negara Lingkungan Hidup No 51 tahun 2004, salinitas yang memenuhi standar baku mutu adalah $33-34$ \% . Hal ini masih sesuai dengan salinitas alami yang dipengaruhi oleh kondisi musiman. Salinitas yang optimal untuk kehidupan spons berkisar $30-36$ $\%$ (Amir \& Budiyanto, 1996).

Derajat keasaman suatu perairan sangat berpengaruh terhadap kehidupan biota air. pH yang rendah (keasaman yang tinggi) kandungan oksigen terlarut akan menurun sehingga menyebabkan aktivitas respirasi organisme naik (Aunurohim \& Subagio, 2013). Parameter pH di Perairan Malang Rapat berkisar 7,63 - 7,78. pH tertinggi terdapat pada stasiun dua sebesar 7,78 dan untuk $\mathrm{pH}$ terendah pada stastiun satu 7,63,. Sedangkan pada stasiun tiga 7,67. Data yang didapat dibandingkan dengan baku mutu air laut KEPMEN LH NO. 51 TAHUN 2004 yaitu berkisar antara 7 8,5. Berdasarkan hasil penelitian kisaran $\mathrm{pH}$ yang didapat masih tergolong baik untuk pertumbuhan spons dan lamun.

Hasil pengukuran oksigen terlarut (DO) yang dilakukan di Perairan Malang Rapat sebesar 6,7- 7,63 mg/l. Nilai oksigen tertinggi terdapat pada stasiun satu yaitu 7,63 sedangkan nilai terendah terdapat pada stasiun tiga yaitu 6,7 dan stasiun dua yaitu 6,8. Berdasarkan KEPMEN LH No. 51 2004. bahwa nilai oksigen terlarut yang baik bagi organisme perairan adalah $>5 \mathrm{mg} / \mathrm{L}$. Hal ini juga didukung oleh pendapat (Suriadarma, 2011). yang mengatakan bahwa hampir semua organisme akuatik menyukai pada kondisi oksigen terlarut $>5 \mathrm{mg} / \mathrm{L}$.

Terjadi penurunan oksigen terlarut pada stasiun dua dan tiga. hal tersebut dikarenakan dengan bertambahnya kedalaman akan terjadi penurunan kadar oksigen terlarut, Proses fotosintesis semakin berkurang dan kadar oksigen yang ada banyak digunakan untuk pernafasan dan oksidasi bahan-bahan organik dan anorganik. Jika dilihat dari hasil pengukuran, maka kondisi oksigen terlarut pada perairan masih baik. Keberadaan oksigen terlarut dalam perairan dimanfaatkan oleh organisme untuk kehidupan, antara lain digunakan untuk proses respirasi. Oksigen digunakan 
untuk proses metabolisme bahan organik sehingga terbentuk energi yang diikuti dengan terbentuknya $\mathrm{CO}_{2}$ dan $\mathrm{H}_{2} \mathrm{O}$ (Marzuki et al., 2014).

\subsection{Substrat}

Hasil pengukuran klasifikasi tipe substrat yang dilakukan di Laboratorium Fakultas Ilmu Kelautan Perikanan Universitas Maritim Raja Ali Haji. Data substrat diperoleh dari hasil pengamatan yang telah diolah disajikan dalam Tabel 5.

Tabel 5. Hasil Pengukuran Tipe Substrat Perstasiun

\begin{tabular}{cccc} 
Stasiun & Fraksi & Lumpur \\
$\mathbf{1}$ & Kerikil & Pasir & $16,8 \%$ \\
$\mathbf{2}$ & $0 \%$ & $83,2 \%$ & $13,5 \%$ \\
$\mathbf{3}$ & $0 \%$ & $86,5 \%$ & $14,7 \%$ \\
\hline
\end{tabular}

Substrat dasar perairan yang didapatkan pada masing-masing stasiun penelitian terdiri dari pasir berlumpur. Hasil di atas menunjukkan tipe substrat di Perairan Malang Rapat pada stasiun I, II dan III yaitu memiliki tipe substrat pasir berlumpur, pada stasiun satu dengan tipe substrat pasir $83,2 \%$, lumpur sebesar $16,8 \%$ dan stasiun dua pasir $86,5 \%$, lumpur sebesar 13,5\% sedangkan stasiun tiga pasir 85,3\%, lumpur sebesar 14,7\%. Dimana lokasi tersebut yang merupakan perairan terbuka menyebabkan pergerakan arus terus menerus sehingga membuat pengadukan sedimen dapat berlangsung secara maksimal. Arus juga kemudian membawa partikel sedimen yang halus dari darat kemudian mengendap didasar perairan. Spons pada umunya ditemukan menempel pada pasir, batu-batuan, dan karang mati hampir pada semua tingkat kedalaman (Panggabean \& Setyadji, 2010).

\subsection{Kerapatan Lamun}

Berdasarkan hasil pengamatan lamun dan identifikasi jenis lamun yang dilakukan di Perairan Malang Rapat dapat dijumpai 4 jenis lamun, yang dapat dilihat pada Gambar 3.

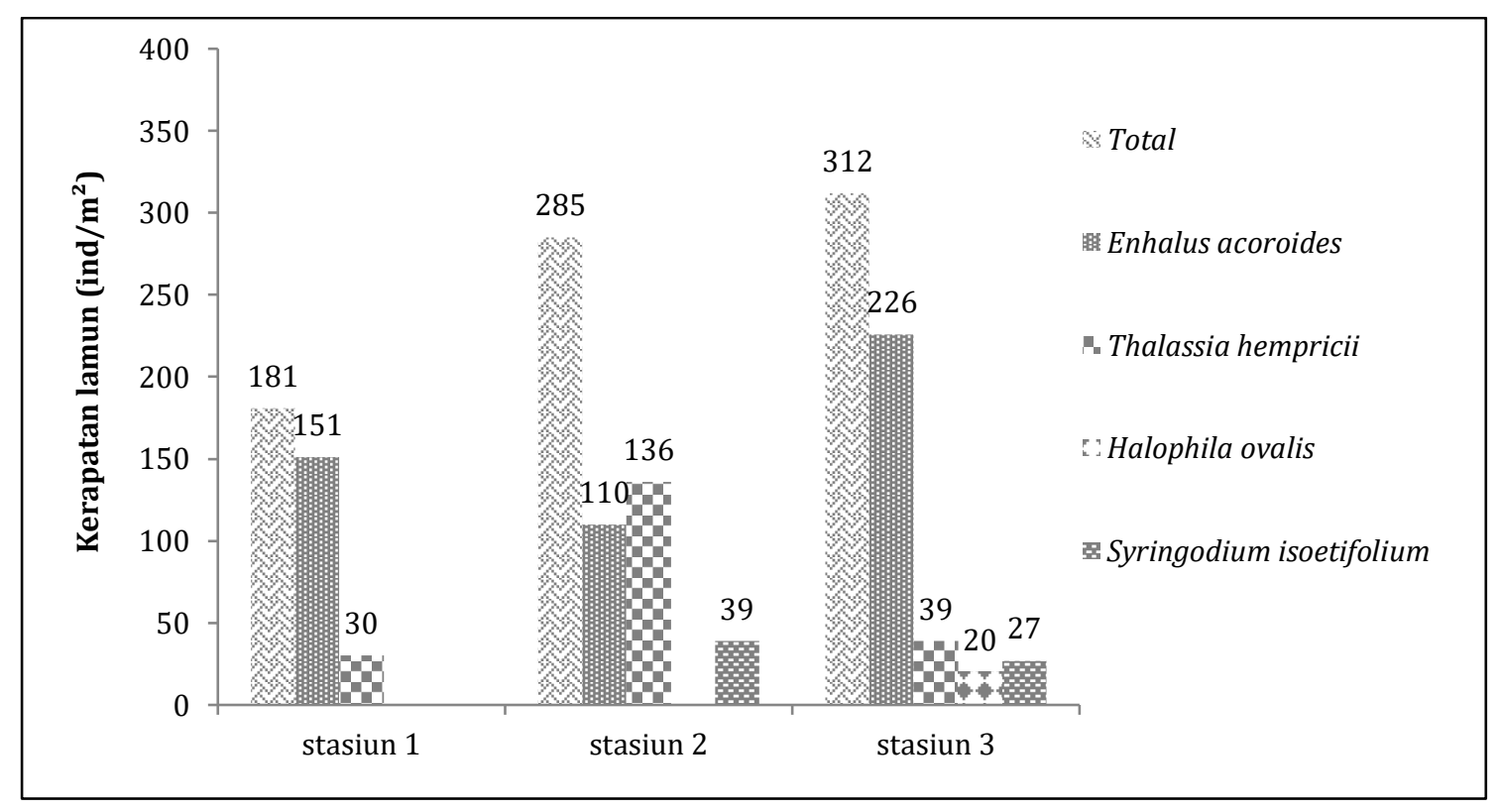

Gambar 3. Kerapatan Lamun

Kerapatan lamun mengacu pada (Gosari \& Haris, 2012) bahwa kerapatan yang sangat jarang bernilai >25 tegakan/ $\mathrm{m}^{2}$ kerapatan yang jarang bernilai 25-75 tegakan $/ \mathrm{m}^{2}$, kerapatan yang cukup rapat benilai $75-125$ tegakan/m², kerapatan yang rapat bernilai 125-175 tegakan/m² dan kerapatan yang sangat rapat bernilai $<175$. Berdasarkan nilai kerapatan lamun yang ditemukan di setiap stasiun dapat di kategorikan bahwa kondisi dari setiap stasiun berada dalam kondisi yang sangat rapat. Stasiun satu nilai kerapatan total sebesar $18 \mathrm{l} \mathrm{ind} / \mathrm{m}^{2}$, sedangkan stasiun dua 285 $\mathrm{ind} / \mathrm{m}^{2}$ dan untuk stasiun tiga sebesar $312 \mathrm{ind} / \mathrm{m}^{2}$. Jenis yang di temukan anatra lain E. acoroides, T. hemprichii, H. ovalis, dan S. isoetifolium.

Faktor yang mempengaruhi kerapatan lamun antara lain, karakteristik substrat luas hamparan padang lamun, sebaran pertumbuhan lamun tidak merata, kedalaman, pergerakan pasang surut air laut, tingginya kerapatan pada stasiun tiga sangat tergantung dari fraksi substrat serta kondisi zat hara substrat dasar tempat lamun tumbuh. Jenis $E$. 
acoroides menyukai substrat dasar pasir dengan kandungan hara tinggi di perairan sehingga jenis ini dominan dan memiliki nilai lebih besar di bandingan jenis yang lain (Haris et al., 2012).

Sebagai perbandingan dari penelitian (Posad et al., 2017) kerapatan lamun tertinggi berada pada substrat lempung berpasir 4455,31 tegakan $/ \mathrm{m}^{2}$, termasuk dalam kategori rapat, kerapatan jenis lamun sedang berada pada substrat pasir berlempung 233,98 tegakan $/ \mathrm{m}^{2}$, termasuk dalam kategori agak rapat dan kerapatan jenis lamun terendah berada pada substrat lempung 180,65 tegakan $/ \mathrm{m}^{2}$, termasuk dalam kategori jarang. Perbedaan kerapatan lamun pada wilayah penelitian di sebabkan oleh kondisi lingkungan tempat pertumbuhan lamun yang berbeda, Kerapatan lamun akan semakin tinggi bila kondisi perairan dalam keadaan baik dan substrat sebagai tempat media lamun tumbuh, arus yang tidak terlalu kuat.

\subsection{Kepadatan Jenis Spons}

Hasil identifikasi kelimpahan jenis spons yang ditemukan di Perairan Malang Rapat Kecamatan Gunung Kijang Kabupaten dapat dilihat pada Tabel 6.

Tabel 6. Kepadatan Spons

\begin{tabular}{ccccl} 
No & Stasiun & Lamun (ind $/ \mathbf{m}^{\mathbf{2}}$ ) & Kepadatan $\left(\mathbf{i n d} \mathbf{\mathbf { m } ^ { 2 }}\right)$ & Substrat \\
1 & 1 & 181 & 5,6 & Pasir berlumpur \\
2 & 2 & 285 & 6 & Pasir berlumpur \\
3 & 3 & 312 & 5,2 & Pasir berlumpur \\
\hline
\end{tabular}

Spons laut dapat hidup di berbagai habitat seperti pasir, karang mati, batu serta pada media yang mempunyai struktur keras. Pada substrat pasir berlumpur spons laut dapat melekat dengan baik.Oleh karena itu, spons dikatakan bersifat sessil yang artinya melekat dan menetap pada suatu substrat (Rumampuk, 2017). Nilai total kelimpahan spons pada stasiun satu sebesar $5,6 \mathrm{ind} / \mathrm{m}^{2}$ dan untuk stasiun dua sebesar $6 \mathrm{ind} / \mathrm{m}^{2}$, sedangkan stasiun tiga sebesar $5,2 \mathrm{ind} / \mathrm{m}^{2}$. Kelimpahan total spons di habitat lamun yang paling tinggi terdapat di stasiun dua yaitu sebesar $6 \mathrm{ind} / \mathrm{m}^{2}$. Stasiun tersebut dicirikan dengan kerapatan lamun yang agak rapat. Pada stasiun satu jenis yang dijumpai seperti Cinachyra sp sebanyak 15 ind, Raspailia arbuscula 13 ind, dan untuk stasiun dua dengan jenis Cinachyrella sp 20 ind, Tetrapocillon novaezealandiae 8 ind, Dendrilla antarctica 17 ind, sedangkan pada stasiun tiga dengan jenis yang dijumpai Petrosia sp 13 ind. Kerapatan jenis T. hemprichii lebih tinggi dibandingkan jenis yang lain sebesar $136 \mathrm{ind} / \mathrm{m}^{2}$, jika kerapatan lamun tinggi maka kepadatan spons tinggi pada sebesar $6 \mathrm{ind} / \mathrm{m}^{2}$, hal ini terjadi karena spons yang ditemukan di lokasi penelitaian lebih menyukai habitat lamun jenis T. hemprichii pada kondisi yang rapat. Kerapatan lamun tinggi tidak selalu mencirikan kepadatan tinggi, berkurangnya spons bisa juga di pengaruhi oleh ketersediaan nutrient di perairan, semakin sedkit nutrient maka spons jarang ditemukan, dan faktor lingkungan lain seperti kedalaman, semakin dalam periaran maka jenis spons yang ditemukan akan semakin sedikit, berbeda jika pada ekositem terumbu karang spons dijumpai pada kedalaman tertentu sesuai ditemuakannya terumbu karang (Suryanti et al., 2014). Spons yang bersifat sesil harus selalu beradaptasi dengan komponen fisik maupun biotik dari lingkungan sekitarnya kompetisi ruang antara spons dan organisme bentik lainnya (lamun) dapat menyebabkan perubahan komposisi struktur komunitas spon (Asro et al., 2013). Spons yang paling banyak ditemukan di habitat lamun yaitu jenis Cinachyrella sp, jenis spons ini mendominasi pada ekosistem lamun, Cinachyrella sp memiliki warna abu-abu pucat diluar dan kuning cerah di dalam, berbentuk membulat memiliki permukaan berduri,memiliki tekstur sedikit kompresibel (jika ditekan dapat kembali semula). Spons hidup dalam pasir, dengan kedalaman diameter hingga $20 \mathrm{~cm}$, tinggi $15 \mathrm{~cm}$. Ditemukan di daerah terumbu karang dalam (Kelly, 2015). Porifera ini juga tumbuh menempel pada substrat-substrat yang keras seperti bebatuan atau karang (Ismet et al., 2011).

Faktor yang memengaruhi kelimpahan spons antara lain, spons tersebut lebih menyukai habitat yang langsung terpapar sinar matahari, sehingga spons lebih banyak ditemukan di habitat dengan kerapatan vegetasi lamun rendah,substrat, dan kerapatan lamun. Kondisi lingkungan yang memiliki kandungan nutrient lebih tinggi banyak ditumbuhi spons dibandingkan perairan yang rendah nutrien (Thakur \& Muller, 2004). Pengaruh faktor lingkungan terhadap keberadaan spons laut, antara lain kedalaman, dimana semakin dalam suatu perairan maka jumlah spons semakin sedikit tetapi bentuk morfolonya semakin besar dan tinggi, faktor lingkungan yang berbeda di tiap tingkatan kedalamannya, sehingga adaptasi dari spons di setiap tingkatan kedalaman akan berbeda pula (Suharyanto, 2008).

Sebagai perbandingan dari penelitian (Maulana, 2018), persentase kelimpahan spons dari famili Agelasidae, yang terdiri dari Agelas conifera dan Agelas citrina di perairan Pulau Pramuka bisa dikatakan cukup tinggi mencapai 55,8\% dari total seluruh spons yang ditemukan dengan nilai kelimpahan sebesar 4,59 ind $/ \mathrm{m}^{2}$. Di mana Agelas conifera merupakan spesies spons yang memiliki kelimpahan yang paling tinggi 4,44 ind/m2 (53,9\%) dan ditemukan di semua stasiun yang diamati. Kepulauan Seribu dengan kecenderungan sebagian besar spons yang ditemukan di lokasi penelitian lebih menyukai habitat dalam komunitas lamun yang di dalamnya terdapat jenis lamun Cymodocea rotundata serta Thalassia hemprichii pada kondisi yang rapat dengan spesies spons yang didominasi oleh Agelas conifera, Amphimedon viridis, Agelas citrina dan Chondrilla caribensis.

\subsubsection{Jenis-jenis Spons}


Hasil dari pengamatan yang dilakukan di Perairan Malang Rapat dengan mengetahui jenis-jenis. Berikut beberapa jenis spons yang ditemukan berdasarkan pengamatan di Perairan Malang Rapat sebagai berikut :

\section{Cinachyrasp.}

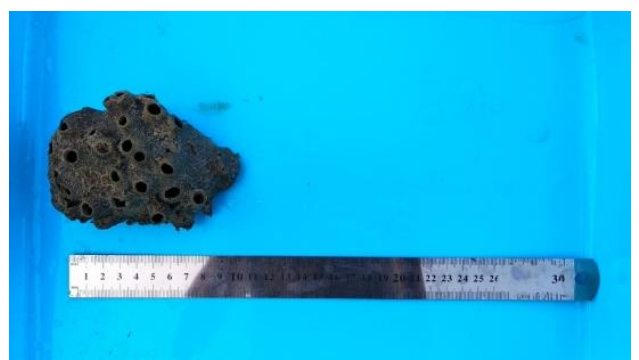

Sumber : Data Primer

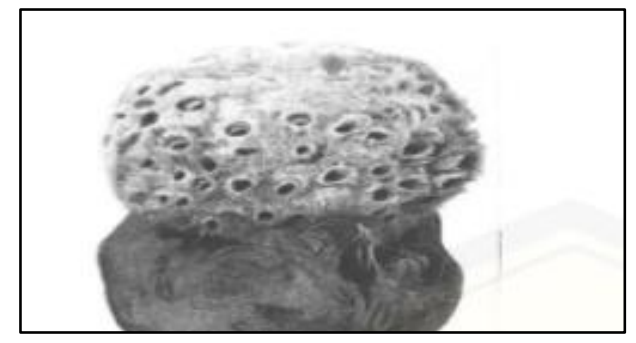

Sumber : (Kelly, 2015)

Gambar 4. Klasifikasi Jenis spons Cinachyra sp.

Klasifikasi Jenis spons Cinachyra sp. (Gambar 4) yang ditemukan di Perairan Malang Rapat Kecamatan Gunung Kijang Kabupaten Bintan adalah sebagai berikut :

$\begin{array}{ll}\text { Kingdom } & \text { : Animalia } \\ \text { Filum } & \text { : Porifera } \\ \text { Kelas } & \text { : Demospongiae } \\ \text { Ordo } & \text { : Spirophorida } \\ \text { Famili } & \text { : Tetillidae } \\ \text { Genus } & \text { : Cinachyra } \\ \text { Spesies } & \text { : Cinachyra sp. }\end{array}$

Memiliki warna abu-abu pucat diluar dan kuning cerah di dalam, berbentuk membulat memiliki permukaan berduri, memiliki tekstur sedikit kompresibel (jika ditekan dapat kembali semula). Spons terkubur dalam pasir, diameter hingga $20 \mathrm{~cm}$, tinggi $15 \mathrm{~cm}$. Ditemukan di daerah terumbu dalam yang rata dalam sedimen ukuran butir sedang yang relatif dalam (Kelly, 2015).

\section{Raspailia arbuscula}

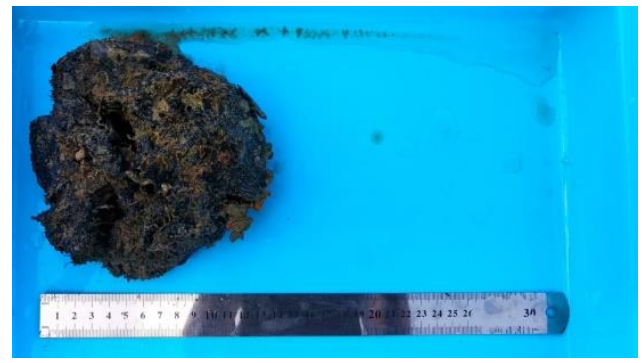

Sumber : Data Primer

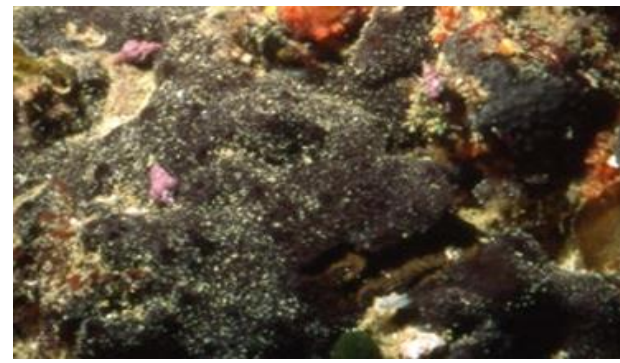

Sumber : (Kelly, 2015)

Gambar 5. Klasifikasi Jenis Spons Raspailia arbuscula

Klasifikasi Jenis spons Raspailia arbusculata (Gambar 5) yang ditemukan di Perairan Malang Rapat Kecamatan Gunung Kijang Kabupaten Bintan adalah sebagai berikut :

$\begin{array}{ll}\text { Kingdom } & \text { : Animalia } \\ \text { Filum } & \text { : Porifera } \\ \text { Kelas } & \text { : Demospongiae } \\ \text { Ordo } & \text { : Axinellida } \\ \text { Famili } & \text { : Raspailiidae } \\ \text { Genus } & \text { : Raspailia } \\ \text { Spesies } & \text { : Raspailia arbuscula }\end{array}$

Mengukus tebal ke spons besar, membentuk tambalan selebar $30 \mathrm{~cm}$, tebal $2-3 \mathrm{~cm}$, hingga $6 \mathrm{~cm}$. Permukaan halus dan bergelombang, Oscula, hingga diameter 2,5 mm, terletak di atas gundukan permukaan. Tekstur tegas, kompresibel, lembut saat disentuh. Warna permukaan dalam kehitaman hitam kecoklatan dengan kemilau keperakan dari spikula yang memproyeksikan, warna internal gelap. Relatif umum, berkerak dalam posisi teduh seperti di bawah tepian batu di intertidal, umum pada tiang dermaga, toleran terhadap kondisi berlumpur. Juga ditemukan di sisi batu-batu besar di terumbu karang terbuka, dari 1-40 m (Kelly, 2015). 


\section{Dendrilla antarctica}

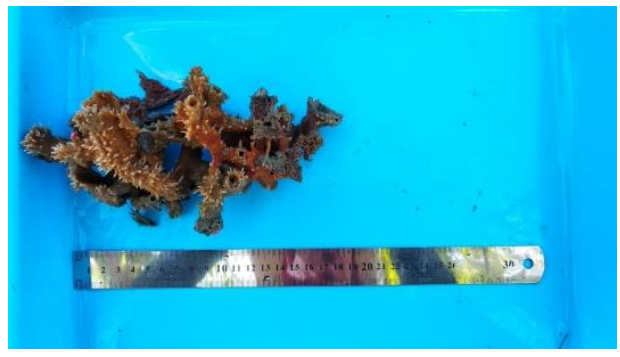

Sumber : Data Primer

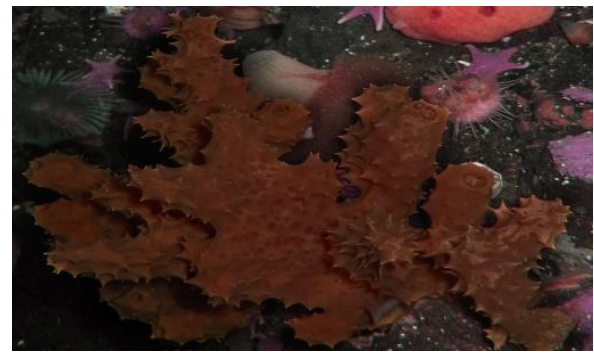

Sumber : (Kelly, 2015)

Gambar 6. Klasifikasi Jenis Spons Dendrilla antarctica

Klasifikasi Jenis spons Dendrilla antarctica (Gambar 6) yang ditemukan di Perairan Malang Rapat Kecamatan Gunung Kijang Kabupaten Bintan adalah sebagai berikut :

$\begin{array}{ll}\text { Kingdom } & \text { : Animalia } \\ \text { Filum } & \text { : Porifera } \\ \text { Kelas } & \text { : Demospongiae } \\ \text { Ordo } & \text { : Dendroceratida } \\ \text { Famili } & \text { : Darwinellidae } \\ \text { Genus } & \text { : Dendrilla } \\ \text { Spesies } & \text { : Dendrilla antarctica. }\end{array}$

Dendrilla antarctica setebal beberapa cm sering kali menutupi permukaan berbatu yang dangkal, kadang-kadang memanjang lebih dari 3 atau 4 meter persegi. Meskipun spesies ini biasanya berwarna kuning hampir bercahaya, spesies ini dapat memiliki beragam warna. Penampilannya yang berduri membuatnya sangat khas tetapi tidak terasa runcing untuk disentuh, jaringannya lembut dan licin. Dendrilla antarctica adalah pesaing yang baik untuk ruang, jadi di bawahnya lembaran kerak sering dapat ditemukan berbagai macam hewan yang telah mati lemas. Jaringan spesies ini memiliki sifat antibiotik dan mengandung diatom endosimbiotik. Seringkali satu atau lebih individu dari siput berasosiasi dengan spons jenis ini. Spons ini biasanya dijumpai menempel pada kerang yang sudah mati. Tumbuh pada substrat karang, spons jenis ini biasanya dijumpai pada perairan dalam dan pada ekosistem lamun (Siska et al., 2018).

\section{Petrosiasp}

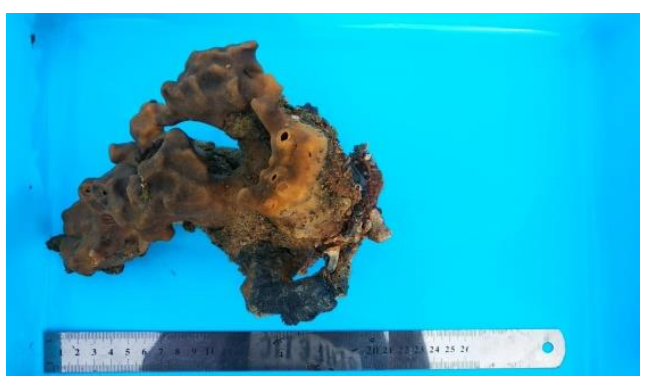

Sumber : Data Primer

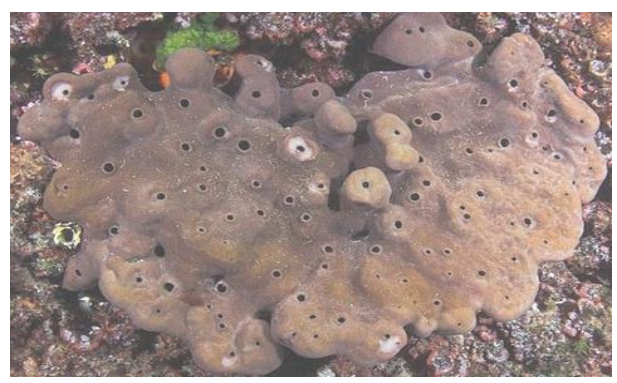

Sumber : (Kelly,2015)

Gambar 7. Klasifikasi Jenis Spons Petrosia sp.

Klasifikasi Jenis spons Petrosia sp. (Gambar 7) yang ditemukan di Perairan Malang Rapat Kecamatan Gunung Kijang Kabupaten Bintan adalah sebagai berikut :

$\begin{array}{ll}\text { Kingdom } & \text { : Animalia } \\ \text { Filum } & \text { : Porifera } \\ \text { Kelas } & \text { : Demospongiae } \\ \text { Ordo } & \text { : Haplosclerida } \\ \text { Famili } & \text { : Petrosiidae } \\ \text { Genus } & \text { : Petrosia } \\ \text { Spesies } & : \text { Petrosia sp. }\end{array}$

Spesies dari famili Petrosidae yang ditemukan adalah Petrosia sp. Petrosiidae memiliki karakteristik berbentuk seperti kawah gunung atau vas bunga, mengerak, membulat atau bercabang. Teksturnya keras hingga rapuh. Bentuk spikulanya monaxon atau tetraxon. Sistem saluran air atau tipe saluran air pada spesies ini adalah leucon atau rhagon. Rangka membentuk kulit yang mengeras, membuat penampilan luarnya terlihat halus. 
Apabila disentuh akan terasa sangat kaku. Porifera ini juga tumbuh menempel pada substrat-substrat yang keras seperti bebatuan atau karang (Ismet et al., 2011).

\section{Tetrapocillon novaezealandiae}

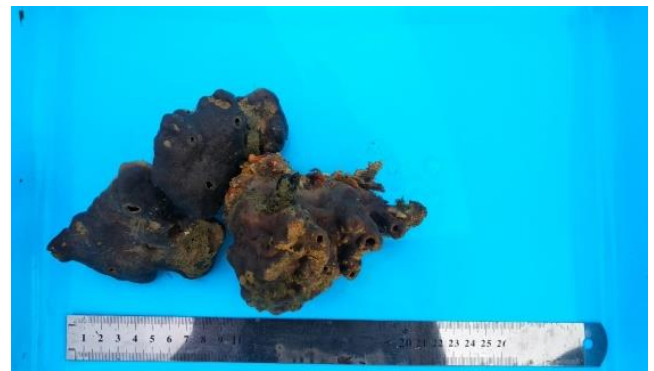

Sumber : Data Primer

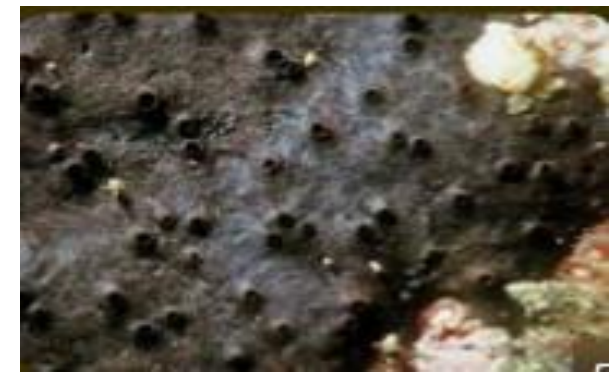

Sumber : (Kelly, 2015)

Gambar 8. Klasifikasi Jenis Spons Tetrapocillon novaezealandiae.

Klasifikasi Jenis spons Tetrapocillon novaezealandiae (Gambar 8) yang ditemukan di Perairan Malang Rapat Kecamatan Gunung Kijang Kabupaten Bintan adalah sebagai berikut :

$\begin{array}{ll}\text { Kingdom } & \text { : Animalia } \\ \text { Filum } & \text { : Porifera } \\ \text { Kelas } & \text { : Demospongiae } \\ \text { Ordo } & \text { : Poecilosclerida } \\ \text { Famili } & \text { : Guitarridae } \\ \text { Genus } & \text { :Tetrapocillon } \\ \text { Spesies } & : \text { Tetrapocillon novaezealandiae }\end{array}$

Spons yang relatif tebal untuk spons gundukan rendah yang membentuk hamparan, sedikit menggelembung di bawah air. Tambalan selebar $70 \mathrm{~cm}$, tebal 5-15 mm. Permukaan mengikuti substrat yang mendasarinya, oskulum sangat kecil, berdiameter 4-6 mm, cukup tersebar di permukaan dan terbentang rata dengan permukaan atau sedikit terangkat. Teksturnya cukup kencang dan lentur di permukaan, di dalamnya rapuh, permukaan terasa lembut saat disentuh. Warna luar hitam ke hijau sangat gelap, warna internal emas kotor oranye-kuning. Umumnya ditemukan berkerak di permukaan batu yang diarsir dan batu-batu besar di perairan subtidal intertidal dan dangkal hingga sekitar $20 \mathrm{~m}$, di garis pantai yang cukup terbuka di sepanjang pantai (Kelly, 2015).

\section{Cinachyrellasp.}

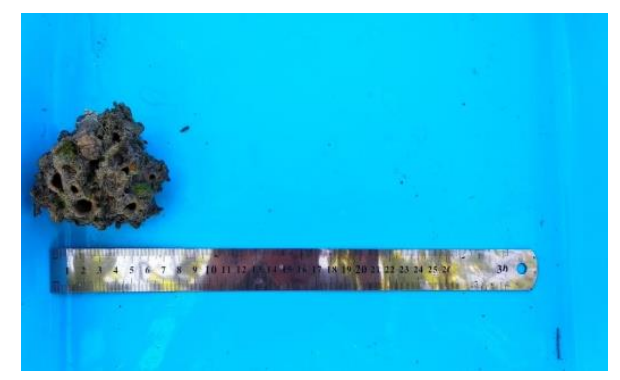

Sumber : Data Primer

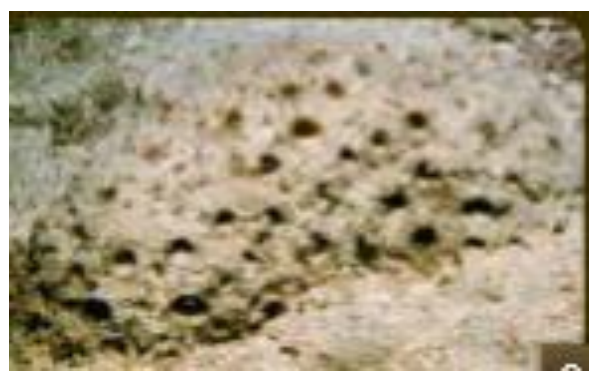

Sumber : (Kelly, 2015)

Gambar 9. Klasifikasi Jenis spons Cinachyrella sp.

Klasifikasi Jenis spons Cinachyrella sp (Gambar 13) yang ditemukan di Perairan Malang Rapat Kecamatan Gunung Kijang Kabupaten Bintan adalah sebagai berikut :

$\begin{array}{ll}\text { Kingdom } & \text { : Animalia } \\ \text { Filum } & \text { : Porifera } \\ \text { Kelas } & \text { : Demospongiae } \\ \text { Ordo } & \text { : Spirophorida } \\ \text { Famili } & \text { : Tetillidae } \\ \text { Genus } & \text { : Cinachyrella } \\ \text { Spesies } & \text { : Cinachyrella sp. }\end{array}$

Spons hemispherical terkubur dalam pasir, diameter hingga $20 \mathrm{~cm}$, tinggi $15 \mathrm{~cm}$. Permukaan dengan spikula memproyeksikan panjang yang memerangkap pasir dan sedimen. Oscules terlihat di permukaan atas dengan pelek berdaging dan beberapa bukaan mengarah ke lubang, sekitar $5 \mathrm{~mm}$ diameter. Tekstur nyaris tidak bisa dikompresi, sangat kasar, lembayung muda, tidak jelas untuk disentuh. Warna dalam hidup tidak jelas, kuning kusam di sekitar 
tepi porocalyce. Dalam warna emas tua. Ditemukan di daerah terumbu dalam yang rata dalam sedimen ukuran butir sedang yang relatif dalam di sekitar Spirits Bay dan pantai Leigh di mana ia berlimpah secara lokal. Di tempat lain distribusinya tidak merata (Kelly, 2015).

\subsection{Indeks Keanekaragaman Spons}

Hasil identifikasi jenis spons yang ditemukan dari lokasi penelitian di Perairan Malang Rapat Kecamatan Gunung Kijang Kabupaten Bintan dikelompokan menjadi 6 spesies yang dimana dapat dilihat pada Tabel 7.

Tabel 7. Indeks Keanekaragaman Spons

\begin{tabular}{cccc} 
No & Stasiun & Indeks keanekaragaman (H') & Kategori \\
1 & 1 & 0,3 & Rendah \\
2 & 2 & 0,4 & Rendah \\
3 & 3 & 0 & Rendah \\
\hline
\end{tabular}

Nilai indeks keanekaragaman pada ketiga stasiun dikategorikan rendah. Nilai indeks keanekaragaman pada stasiun satu dengan kategori rendah, dan untuk stasiun dua dengan kategori rendah, sedangkan nilai indeks keanekaragaman pada stasiun tiga kategori rendah. Menurut Shannon-Wiener tingkat keanekaragaman spons dikatakan rendah apabila $\mathrm{H}^{\prime}<1,6$, sedang $1.6<\mathrm{H}^{\prime} \leq 2.3$ dan $\mathrm{H}^{\prime}>2.3$ dikategorikan tinggi. Perbedaan nilai rata-rata dari indeks keanekaragaman tersebut diduga disebabkan perbedaan jumlah jenis dan individu pada setiap ekosistem. Perbedaan kondisi perairan juga diduga mempengaruhi nilai indeks keanekaragaman (Abdullah, 2006). Keanekaragaman jenis spons pada suatu habitat umumnya ditentukan oleh kondisi perairan yang jernih dan tidak memiliki arus kuat. Sebaran spons dapat ditemui pada setiap kondisi kedalaman yang berbeda dengan tingkat kecerahan yang cukup untuk pertumbuhannya (Abubakar et al., 2011). Faktor kedalaman sangat mempengaruhi bentuk spons. Pada kedalaman 3m, bentuk spons cenderung pendek namun jumlah individu banyak sedangkan pada kedalaman 12m, ukurannya lebih panjang namun jumlah individu sedikit. Hal ini diduga karena pengaruh makanan (kelimpahan plankton), sinar matahari, dan kecepatan arus (Konuklugil \&\& Gozcelioglu, 2015).

Keanekaragaman Jenis spons ini didukung oleh kondisi lingkungan spons itu sendiri. Perbedaan tingkat keanekaragaman jenis di setiap stasiun ini sangat dipengaruhi oleh faktor fisika perairan seperti kecerahan, kedalaman, nutrien, suhu, dan salinitas, oleh karna itu lingkungan selalu menjadi faktor penting untuk mendukung habitat organisme di perairan (Dohrmann et al., 2008). Keanekaragaman jenis spons pada suatu habitat umumnya ditentukan oleh kondisi perairan yang jernih dan tidak memiliki arus kuat, kondisi lingkungan mengharuskan spons tersebut selalu beradaptasi terhadap komponen-komponen fisik maupun biotik yang terdapat pada suatu perairan (Yanti et al., 2020).

Sebagai perbandingan dari penelitian (Haedar et al., 2016) secara umum indeks keanekaragaman spons di lokasi penelitian masuk dalam kategori sedang berkisar antara 1,1l-1,64.Semakin banyak jumlah spesies maka semakin beragam komunitasnya. Perbedaan nilai rata-rata dari indeks keanekaragaman tersebut diduga disebabkan perbedaan jumlah jenis dan individu pada setiap kedalaman. Perbedaan kondisi perairan juga diduga mempengaruhi nilai indeks keanekaragaman.

\subsection{Analisis Kedekatan antara Kerapatan Lamun, Kepadatan Spons dan Parameter Lingkungan Perairan}

Komponen Lingkungan antara keanekaragaman spons dan kerapatan lamun dapat diketahui dari hasil analisis menggunakan Analisis Komponen Utama (AKU) atau sering disebut dengan Principal Component Analysis (PCA) dengan software minitab 17.1 pada Gambar 10.

Hasil analisis PCA terhadap matriks korelasi data kepadatan spons, kerapatan lamun dan parameter lingkungan perairan menunjukan adanya penciri stasiun pengamatan dengan karakter penciri lingkungan, dapat dilakukan dengan melihat besar kecilnya sudut yang dibentuk masing-masing (Maulana, 2018). Berdasarkan gambar di atas pada stasiun satu parameter lingkungan perairan tidak memiliki kedekatan dengan kerapatan lamun dan kepadatan spons. Sedangkan pada stasiun dua kepadatan spons memiliki kedekatan dengan parameter lingkungan perairan seperti pH dan suhu, pada stasiun tiga kerapatan lamun memiliki kedekatan dengan parameter lingkungan perairan seperti salinitas dan kecerahan. 


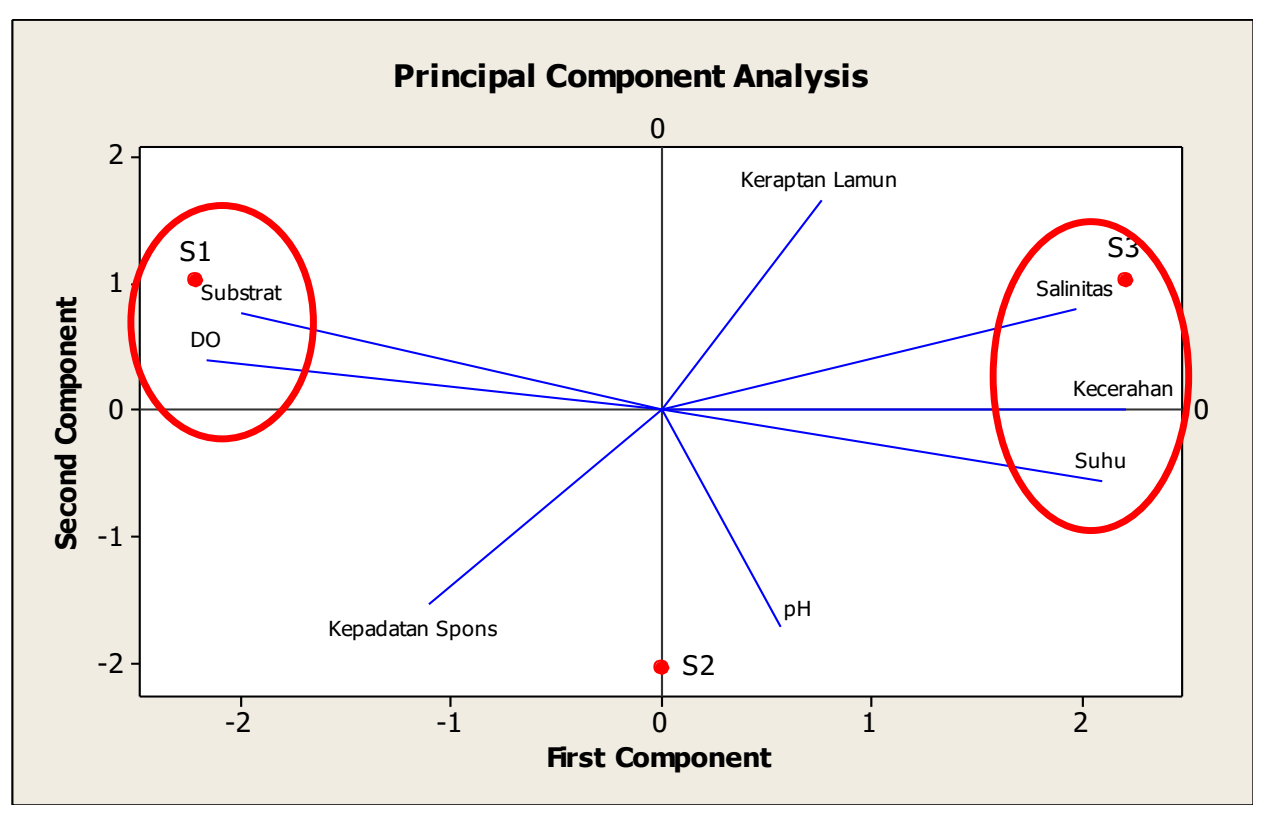

Gambar 10. Principal Component Analysis (PCA)

Ekosistem lamun memiliki toleransi terhadap salinitas yang berbeda pada kisaran $10-40 \%$, dengan nilai optimum toleransi salinitas air laut yang baik bagi pertumbuhan lamun sebesar $35 \%$ (Hoek et al., 2016), sehingga memiliki akar ciri antara kerapatan dan salinitas untuk menunjang pertumbuhan dan perkembangan lamun, kecerahan perairan yang optimal untuk pertumbuhan lamun mencapai 100\%, sehingga proses fotosintesis dapat berajalan dengan baik yang akan mendukung pertumbun lamun, kecerahan menjadi faktor penting dalam kehidupan ekosistem lamun, sehingga kerapatan lamun memiliki akar ciri dengan parameter kualitas perairan seperti kecerahan (Lemloh, 2009). Kondisi perairan memiliki peranan penting dalam mendukung kehidupan spons, kondisi perairan yang sesuai dengan kehidupan spons dialam menyebabkan tingkat kepadatan spons semakin tinggi. Sedangkan $\mathrm{pH}$ parameter paling sensitif yang memengaruhi pertumbuhan spons, keasaman $(\mathrm{pH})$ mempunyai pengaruh yang sangat besar terhadap organisme perairan seperti spons (Rachmat, 2007).

\section{SIMPULAN}

Kesimpulan dari penelitian ini yaitu kerapatan lamun di Perairan Malang Rapat Kecamatan Gunung Kijang Kabupaten Bintan di kategorikan sangat rapat pada semua stasiun. Kepadatan spons tertinggi dijumpai pada stasiun dua, sedangkan pada stasiun satu dan tiga memiliki kelimpahan rendah. Hasil analisis PCA stasiun satu parameter lingkungan perairan tidak memiliki kedekatan dengan kerapatan lamun dan kepadatan spons. Sedangkan pada stasiun dua kepadatan spons memiliki kedekatan dengan parameter lingkungan perairan seperti $\mathrm{pH}$ dan suhu, pada stasiun tiga kerapatan lamun memiliki kedekatan dengan parameter lingkungan perairan seperti salinitas dan kecerahan.

Adapun saran berdasarkan hasil penelitian di wilayah ini adalah, Pada saat pengamatan spons di lapangan harus diidentifikasi langsung di lapangan karena jika spons tidak diidentifikasi langsung dilapangana akan menyebabkan spons mati dan mengalami perubahan warna pada spons. Identifikasi dari karakteristik morfologi secara langsung atau spikulanya agar memudahkan dalam mengidentifikasi jenisnya, perlu dilakukannya penelitian lebih lanjut mengenai spons pada habitat karang sehingga hasil yang di dapatkan dapat maksimal.

\section{REFERENSI}

Abubakar, H., Wahyudi, A.T., \& Yuhana, M. (2011). Skrining Bakteri yang Berasosiasi dengan Spons Jaspis sp. Sebagai Penghasil Senyawa Antimikroba. Jurnal Ilmu Kelautan. 16(1):35-40.

Abdullah, A. (2006). Isolasi dan Identifikasi Mikroba Simbion Spons Axinella sp. Jurnal Ilmu Pertanian Indonesia. 11(3):1-5.

Amir, I., \& Budiyanto, A. (1996). Mengenal Spons Laut (Demospongiae) Secara Umum. Oseana. (21):15-31.

Asro, M., Yusnaini, \& Halili. (2013). Pertumbuhan Spons (Stylotella aurantium) yang Ditransplantasi Pada Berbagai Kedalaman. Jurnal Mina Laut Indonesia. 1(1):133-144.

Aunurohim, \& Subagio, I.B. (2013). Struktur Komunitas Spons Laut (Porifera) di Pantai Pasir Putih. Situbondo. Jurnal Sains \& Seni ITS. 2(2):2337-3520.

Bakus, G.J. (2007). Quantitative Analysis of Marine Biological Communities: Field biology and environment. John Wiley \& Sons, Inc. New Jersey. 435 hal.

DKP Kabupaten Bintan. (2011_. Profil Kelautan dan Perikanan Kabupaten Bintan. Dinas Kelautan dan Perikanan. Kabupaten Bintan.

Dohrmann, M., Janussen, D., Reitner, J., Collins, A.G., \& Worheide, G. (2008). Phylogeny and Evolution of glass sponge (Porifera, Hexactinnelida). Systematic Biology. 57(1):388-405.

Fachrul, M.F. (2007). Metode Sampling Ekologi. Bumi Aksara: Jakarta. 
Gosari, J.A, \& Haris A. (2012). Studi Kerapatan dan Penutupan Jenis Lamun di Kepulauan Spermonde. Torani. Jurnal Ilmu Kelautan dan Perikanan. 22 (3): 256-162.

Haris, A., Soedharma, D., Zamani, N.P., Pariwono, J.L., \& Rachmaniar. (2012). Seksualitas dan Perkembangan Gamet Spons Laut Aaptos aaptos Schmidt. Jurnal Natur Indonesia. 14(3):205-211.

Haedar, Sadarun, B., \& Palupi, D.R. (2016). Potensi Keanekaragaman Jenis dan Sebaran Spons Di Perairan Pulau Saponda Laut. Kabupaten Konawe. Sapa Laut: Jurnal Ilmu Kelautan. 1(1): 1-9.

Hoek, F., Abu, D., Razak, Hamid, Muhfizar, Suruwaky, A.M., Ulat, M.A, Mustasim, \& Arfah, A. (2016). Struktur Komunitas Lamun Di Perairan Distrik Salawati Utara Kabupaten Raja Ampat. Jurnal Airaha. 5(1):87-95.

Ismet, M.S., Soedharma, D., \& Effendi, H. (2011). Morfologi dan Biomassa Sel Spons Aaptos aaptos dan Petrosia sp. Jurnal Ilmu dan Teknologi Kelautan Tropis. 3(2): 153-161.

Kawaroe, M., Nugraha, A.H., Juraij, \& Tasabaramo, I.A. (2016). Seagrass Biodiversity At Three Marine Ecoregions of Indonesia: Sunda Shelf, Sulawesi Sea, and Banda Sea. Biodiversitas Journal of Biological Diversity. 17(2):585-591.

Kelly, M. (2015). Splendid Sponges a guide of the Sponges of new Zealand. Version 1. NIWA TC Media Ltd. New Zealand.

Kepmen Lingkungan Hidup No. 51 Tahun 2004 tentang baku mutu kualitas air laut untuk biota laut.

Konuklugil, B., \& Gozcelioglu, B. (2015). Antimicrobial Activity of Marine Samples Collected From the Different Coasts of Turkey. Turkish Journal of Pharmaceutical Sciences. 12(3):337-344.

Lemloh, M.L., Fromont, J., Brümmer, F., \& Usher, K.M. (2009). Diversity and abundance of photosynthetic sponges in temperate Western Australia. BMC Ecol. 9(4):1-13.

Marzuki, I., Noor, A., Nafie, N.L., \& Djide, M.N. (2014). Isolasi dan Identifikasi Bakteri Shimbion Spons Penghasil Enzim Amilase Asal Pantai. Balikpapan. Jurnal Ilmiah. 1 (2): 11-18.

Maulana, M.I. (2018). Hubungan Morfotipe Lamun Dan Spons Di Perairan Pulau Pramuka. Kepulauan Seribu. Fakultas Perikanan Dan Ilmu Kelautan. Institut Pertanian Bogor.

Panggabean, A.S., \& Setyadji, B. 2010. Pengaruh Substrat dan Kedalaman Terhadap Pertumbuhan Spons (Callyspongia sp.) di Perairan Jepara. BAWAL Widya Riset Perikanan Tangkap. 3(3):175-181.

Posad, J., Ira, \& Afu., L.O.A. (2017). Distribusi Spasial Lamun Berdarkan Kerapatan di Perairan Desa Sawapudo Kabupaten Konawe. Sapa Laut: Jurnal Ilmu Kelautan. 2(3):89-95.

Rachmat, R. (2007.) Spons indonesia Bagian Timur Keragaman, Distribusi, Kelimpahan, dan Kandungan Metabolik Sekundernya. Oseanologi dan Limnologi di Indonesia. 3(1):123-138.

Rahmawati, S., Supriyadi, I.H., \& Azkab, M.H., \& Kiswara, W. (2014). Panduan Monitoring Padang Lamun. COREMAP CTI LIPI. Jakarta.

Rumampuk, Y.B.J., Wowor, P.M., \& Mambo, C.D. (2017). Uji Daya Hambat Ekstrak Spons Laut (Callyspongia aerizusa) terhadap Pertumbuhan Bakteri Salmonella typhia dan Streptococcus pyogenes. Jurnale-Biomedik (eBm).5(2):1-7.

Sabdono, A. (2011). Microbial Symbionts in Marine Sponges Marine Natural Product Factory. Journal of Coastal Development. 11(2):5761.

Siska, Puspita, L., \& Sari, P.N. (2018). Struktur Komunitas Porifera (Spons) Di Perairan Pulau Layang dan Pulau Cokus Kelurahan Skanakraya. Kota Batam Kepulauan Riau. Simbiosa. 7(2): 109-121.

Suharyanto. (2008). Distribusi dan persentase tutupan sponge (porifera) pada kondisi terumbu karang dan kedalaman yang berbeda di perairan pulau barranglompo, sulawesi selatan. Biodiversitas. 9(3): 209-212.

Suriadarma, A. (2011). Dampak Beberapa Parameter Faktor Fisik Kima Terhadap Kualitas Lingkungan Perairan Wilayah Pesisir Karawang. Jawa Barat. Riset Geologi dan Pertambangan. 21(1):21-36.

Suryanti, Ain, C., \& Tishmawati, C.N. (2014). Hubungan Kerapatan Lamun (Seagrass) dengan Kelimpahan Syngnathidae di Pulau Panggang Kepulauan Seribu. Journal of Maquares. 3(4):147-153.

Thakur, N.L., \& Müller, W.E.G. (2004). Biotechnological potential of marine sponges. Current Sci. 86(11): 1506-1512.

Yanti, H., Palupi, R.D., \& Rahmadani. (2020). Keanekaragaman dan Kepadatan Spons di Perairan Lalowaru Sulawesi Tenggara. Sapa Laut: Jurnal Ilmu Kelautan. 5(1): 61-67. 